\title{
Turkish Foreign Policy towards Syria since 2002
}

\author{
Mira A. Abdel Hameed ${ }^{1}$ \& Mohamed Mohamed Hussein Mostafa ${ }^{1,2}$ \\ ${ }^{1}$ Faculty of Economics and Political Science, Cairo University, Giza, Egypt \\ Correspondence: Mira A. Abdel Hameed. E-mail: Mira.feps.cu@Gmail.com
}

Received: November 9, 2017

doi:10.5539/ass.v14n2p57

\author{
Accepted: December 15, 2017 Online Published: January 29, 2018 \\ URL: https://doi.org/10.5539/ass.v14n2p57
}

\begin{abstract}
Since Justice and Development Party (AKP) came to power, Turkey has been transformed from an isolated country from its regional environment to a regional player which had positive relations with most countries in the region, especially Syria. It represents a strategic importance for Turkey. Turkey's policy towards Syria since 2002 has aimed at reviving its regional role, protecting its national security and achieving its economic interests. The problem of the study revolves around the nature of the determinants and orientations of Turkish foreign policy towards Syria, and changes that have taken place in this policy from the moment of the arrival of AKP to power to the period following the Syrian Revolution. The predicament here is the difficulty in following a general feature of Turkish policy towards Syria, from one stage to another, specifically before and after the revolution.

Therefore, the study seeks to know the nature of this policy and its tools, and the extent of its impact on the relations between the two countries. The Syrian Revolution is difficult test for Turkey. To get out of the regional dilemma, Turkey has reoriented its foreign policy. The study has reached several points of results, the most important of which are:

1) The change in the Turkish ruling elite since 2002 has been a major factor in the change of Turkish foreign policy towards Syria. 2) Despite the importance of the water factor in Turkish policy towards Syria, it reflected the development of relations between them. If relations between the two countries were good, the talk about conflict over water would decline. 3) Turkey's decision- makers have expected that the Arab revolutions would have a positive impact on the Turkish role in the region. However, the Syrian revolution had a negative impact on turkey and its regional project. 4) AKP has reconsidered ideology as a key determinant of foreign policy after the Arab revolutions by supporting the opposition. However, ideology has retreated in front of the state's interests. This was evident in the changes of Turkish foreign policy after the failed coup in Turkey. 5) The Syrian crisis has proved that Turkey cannot engage in Syria away from the calculations of regional and international powers.
\end{abstract}

Keywords: Turkish Foreign Policy, Kurds, Water Issue, Syrian Revolution

The current study deals with the Turkish foreign policy towards Syria since 2002 through four axes:

\section{Determinants of Turkish Foreign Policy towards Syria}

Turkey sets the determinants of its foreign policy in accordance with national interest standards and changes in international and regional environment. The internal and external determinants are:

\subsection{Internal Determinates}

\subsubsection{Geographical Determinant}

Syria is in the south of Turkey. This location is the main crossing of Turkey to the southern regions in Syria and beyond. Its location in the region of Fertile Crescent is of great importance to the Turkish project. This location, also, is an advanced front with Israel (Bakeir, 2013). Owing to the annexation of Turkey of Sanjak of Alexandretta (Iskenderun Brigade) and the problems of water, the geographical neighborhood between both countries served as a factor of conflict. However, these problems have not been controversial issues since the improvement of relations between them.

\subsubsection{Military Institution}

The military Institution has escalated the language of the Turkish official discourse on Syria. It also opposes Turkey's opening policy in Syria depending on allegation that Syria was one of the countries that threatened 
Turkey's national security. In addition to this, Turkey was committed to an alliance with Israel. The signing of the military cooperation agreement between Turkey and Israel led to the adoption of Turkish foreign policy for escalating situations towards Syria. Despite the diminishing influence of the military Institution after the arrival of AKP to power, it still has an impact on Turkey's foreign policy. It was opposed to the government's requests to intervene in Syria.

\subsubsection{The Influence of Erdogan's Intellectual Orientations on Turkish Foreign Policy towards Syria}

The political leader's ideas affect foreign policy change. Erdogan is the most prominent leader in Turkey's foreign policy- making process because prime minister in Turkey is primarily responsible for foreign policy decisions. In addition, Erdogan has a charisma. Erdogan's ideological belief, which derived from his early life, religious education and Turkish history, affected the formulation of foreign policy orientations. Erdogan's autobiography shows his Islamic background. He graduated from the high school of imams and Preachers and joined the National Safety Party known as its religious orientation (Mohamed, 2013). The religious education affected his political orientations. He said, when he was the mayor of Istanbul in 1996, "I am a servant of the Islamic law and I am the imam of Istanbul". Erdogan was imprisoned because of his ideas which close to Erbakan's ideas. After the dissolution of the Welfare Party, he felt that his adoption of Erbakan's approach might hamper his political course. When he founded AKP in 2001, he tried to take his party away from its religious character. "We are not an Islamic party, but we are democratic Muslims", he said. His political experience affected his vision of foreign policy. He adopted the approach of Oglu based on openness to all states. Erdogan rejects the idea that Turkey's approach to the Arab countries means that it is moving away from the West. He believes that the main objective of Turkey is the development of relations with the Arab countries, especially Syria. In addition, the common cultural heritage between Turkey and Arab countries contributed to the development of economic relations between them, supporting the foreign policy based on peace.

\subsection{The External Determinants}

\subsubsection{The Regional Determinants}

\subsubsection{Israel}

Turkish- Israeli relations are one of the most important determinants of Turkish foreign policy towards Syria. According to Israel, Syria is an enemy. Turkish- Israel relations gained a great importance since the establishment of Israel until 2002. This is due to many agreements concluded at that period. The Jewish community in Turkey, which is one of the most influential communities there, played an important role in consolidating relations between Turkey and Israel. The most significant stage in relations was the signing of the agreement of military cooperation in 1996. The Justice and Development government has committed itself to agreements signed with Israel at the expense of Syria. For example, in September 2007, Israel bombed a Syrian facility in Deir al- Zour, violating Turkish airspace. Israel apologized for violating it. This raised again the nature of the military cooperation between both countries and the limits of such cooperation (Yousef, 2013). Although Turkey's relationship with Israel is an obstacle to Turkey's openness to Syria, Turkey has managed to play the role of mediator between Syria and Israel. However, in 2010, relations between the two countries deteriorated because of Freedom Flotilla crisis. Nevertheless, Israel sees Turkey as an indispensable ally because it needs to use Turkey's strategic depth to defend itself.

\subsubsection{Iran}

Apart from the historical sectarian rivalry between Turkey and Iran, their relationship was affected by developments after the US- led war on Iraq in 2003. While Iran tried to exploit the vacuum created after the collapse of the Iraqi regime, Turkey tried to exploit the official Arab hostility to Tehran to extend its influence. Nevertheless, the Justice and Development Party was aware of Iran's importance to benefit from oil and gas. Therefore, Turkey tried to improve relations with Iran by signing several agreements. Furthermore, Turkey supported Iran in its nuclear file for peaceful purposes (Demir, 2017).

Iran is a major determinant of Turkish policy towards Syria. Iran has been able through the Iranian- Syrian alliance, to extend its regional influence from western Iran, Iraq to Syria. Also, Syria guarantees the access of Iran to the line of Palestinian cause, which will achieve positive results for the Iranian regional project (AlLabad, 2013). Therefore, Iran has been closely following Turkey's mediation between Israel and Syria, fearing that Turkey may exclude it regarding some of its options in the region. Any Israeli- Syrian peace will make Syria separate from Iran.

\subsubsection{International Determinates}

Since the world constitutes the political framework states, especially in penetrating regional systems such as the 
Middle East, the international environment sets limits on Turkey's foreign policies within the framework of the global order dominated great powers (Mahfoud, 2009).

\subsubsection{The United States}

Relations between Turkey and the United States have been strong since the end of World War II because of Turkish security considerations, especially the Russian obsession and the desire for aid. Turkey has could present itself to the United States as a reliable partner. After the events of September 11, Turkey supported the United States in its wars on terrorism, and in return the United States supported Turkey in its demand for joining the European Union (Kardas, 2011).

The United States is one of the major international determinants of Turkish foreign policy. According to the United States, Syria is a strategic regional state, without which peace cannot be achieved. Thus, the role of Turkey in the region has significantly increased as a result of its openness to Syria. The United States held that Turkish- Syrian relations could be used as a means of pressure through dialogue. Indeed, Turkey mediated between Israel and Syria. At first, the US administration, which sought to isolate Syria, did not welcome it. However, it turned out that the United States was counting on Turkey's ability to dissuade Syria from its defensive approach and penetrate the relationship between Damascus and Tel Aviv, without increasing Syria's presence in the regional scene, as well as the disengagement between Tehran and Damascus (Al- Anani, 2010).

\subsubsection{Russia}

Russia is one of the most influential international determinants of Turkey's foreign policy towards Syria. The Russian- Syrian alliance was formed during the Cold War. Since the end of that period, Syria has been one of Russia's remaining geopolitical sites in the Middle East. Russia maintains a naval base in the Syrian port of Tartous. This base is important because Russia aspires to play a larger role in the Middle East (Trenin, 2014). Syria has also declared its support for the Russian military operation in Georgia in 2008. Therefore, Russia opposes overthrowing Assad and rejects any military intervention. Also, it has provided immunity to Assad in the Security Council. Consequently, Russia opposes Turkey on the process of supporting the Syrian opposition.

\section{Turkish Foreign Policy issues towards Syria}

The 1998 Adana Agreement between Turkey and Syria ended tensions between them and relations began to improve. The winning of AKP in 2002 elections gave impetus to these relations. In this vein, the study clarifies the issues of Turkish foreign policy toward Syria before and after taking the party power. Turkey's post- Cold War foreign policy sought to play a regional role in the region through sensitive issues such as water issue and Kurdish one. Such issues were a major reason for deteriorating Turkish- Syrian relations. After taking the party power, several issues in the Turkish policy towards Syria placed on the top of priorities such as the revival of Turkey's regional role, the Kurdish issue, economic relations and the Syrian revolution.

\subsection{Water Issue}

Syria and Iraq demand a fair and final distribution of water of Tigris and Euphrates, which Turkey rejects. Turkey denies the international status of the two rivers and considers both Turkish rivers crossing the border.

Negotiations have been failed. Ankara committed to allow an average of 500 cubic meters per second of Euphrates water under the 1987 protocol (Tayie, 2012). The dispute over the Euphrates River erupted in 1990 when Turkey began filling Ataturk Dam's reservoir. Turkey rejects the principle of division or distribution of water and accepts the principle of optimal use of water, which is rejected by Syria. Therefore, it used Kurdistan Worker's Party (PPK) as a pressure card when water issue is raised. Tension increased in 1998, but Syrian-Turkish relations improved when the Adana agreement has been signed.

Despite the importance of water factor in Turkish policy towards Syria, it reflects the developments of political relations between them. In 2008, the two countries intensified their efforts to establish the Friendship Institute to deal with water issue and establish the Friendship Dam on the Orontes River in the border area between them. This is important for Turkey because this region falls within the administrative boundaries of the sanjax of Alexandretta (Iskenderun) in Syria. The approval of Syria of the project on these borders indicates that Syria officially recognizes that the sanjax of Alexandretta locates within the borders of Turkey. The percentage of the benefit from it is $50-50 \%$ for both parties. Turkey has expressed its willingness to increase the amount of water to Syria without an agreement to divide water between them. This indicates that Ankara insists on dealing with the issue of water in the same old way, despite the development of relations between the two countries (Ibrahim, 2015). 


\subsection{The Kurdish Issue}

The Turks were able to link the issue of PPK with the issue of water in relations with Syria. Turkey's Kurdish policy towards Syria reached its peak in October 1998, but the Adana agreement has been concluded and the Syrian borders have been closed to prevent the fighters of PPK from crossing the borders. Ankara has managed to encircle the PPK's security danger from 1984 to 2013. At the political level, however, the Kurdish problem has not been resolved in Turkey.

The variables of the Kurdish issue, especially after 2003, helped the two countries to be compatible. There were common concerns about the Kurdish issue during the period of US occupation of Iraq, especially after Iraq's Kurds achieved autonomy in 2004, which is an incentive for Kurds in neighboring countries. This entity is a danger to Turkey because it is a buffer zone to which prevent Turkey from expanding regionally. In particular, Turkey's geographical entrances to the Arab countries are only Iraq and Syria. As relations improved, Syria launched military operations in 2003 against the bases PPK on the border of Turkey and Syria. Also, Syria supported Turkish military operations against the militants of the party in northern Iraq in 2008.

\subsection{Mediation in Syrian-Israeli Negotiations:}

Turkey has acted as a mediator in the Syrian- Israeli negotiations in 2008. Turkish mediation efforts, however, date back to 2006, when Turkey conveyed a message from Israel and Syria that Syria should stop supporting terrorist organization such as Hezbollah and Hamas (Bar, 2006). Turkey has sought to play a regional role by such mediation. The success of mediation stays Iran away from Al- Mashreq. Furthermore, Turkey wants to change the world's vision about it, from an ally of Israel and the West to a mediator between Syria and Israel. Erdogan's efforts in the issues of the Middle East also reflect the return of the Ottomans as a third regional alternative in the Middle East region on the two main competing lines in the region which are Iran and Syria on the one hand, and Egypt and Saudi Arabia on the other (Abdel- Aziz, 2008). There are two factors that helped Turkey to play the role of mediator. First, the parties of the conflict trust in Turkey. Second, Turkey's economic relations with Syria and Turkey are significantly increasing.

\subsection{Syrian Crisis}

The Turkish situation on the Syrian crisis was related to several determinants, which affected Turkey's dealing with this crisis. These determinants are: 1) the importance of Syria to the Turkish policy, Syria is the most successful example of the zero-problem policy. 2) Turkey fears that a sectarian conflict in Syria might occur which threatens stability within it. 3) there is a regional competition between Turkey and Iran. Therefore, Turkey initially adopted a more cautious stance to change the regime in Syria and pressured to begin reforms. However, the Syrian regime did not respond and used force. Thus, Turkey hosted the Syrian opposition. Turkey also tried to intervene in Syria under the guise of an international front. However, this attempt has been suppressed by Russia and China which used the right of veto. Accordingly, the Syrian National Council is the best way for Turkey to penetrate Syria and control over the Kurdish issue. In February 2012, Turkey called for the opening of humanitarian passageways along the border with Syria (Fantappie, 2012).

With the outbreak of the Syrian crisis and the emergence of the PKK as the strategic factor in Syria, the need to contain it has increased. The Syrian regime provided the party with facilities to carry out military operations against Turkey. In summer of 2012, the regime withdrew from some Kurdish areas in north-east and north- west Syria, and handed over its administration to the Democratic Union Party (BYD). Therefore, in spring of 2013, the Turkish government launched a peace process with PPK to reach a political solution. The peace process was in line with Turkey's political calculations where it wants to gain the support of Kurds in the presidential elections of the year of 2014.

With the development of the events, the Front of Nasra and the Islamic State in Iraq and Syria(ISIS) became the two prominent jihadist groups that occupied large parts in north and north- east Syria. Turkey provided support to the Mujahedin because they are the most effective against Al- Assad. It allowed them to cross and provided them with weapons and training (Hinnebusch, 2015). Clashes erupted between the forces of BYD and the Jihadi groups, putting Turkey in front of a difficult decision.

Kobani crisis came as a result of its siege by ISIS. Turkey has refused to provide support, while the United States has supported Kurdish fighters in Kobani. This is because Turkey realizes that supporting the Kurds will contribute to strengthening PPK. In October 2014, Turkey agreed to cross the Peshmerga to Syria. The victory of the Kurds in Kobani was a blow to Turkey's peace process with its Kurdish (Barkey, 2016). Peace talks broke down with the Turkish government in the summer of 2015. PPK launched a number of attacks in Turkey. It can be said that the Turkish objectives in Syria after the revolution were: 
- The establishment of a buffer zone in Syria

Turkey wanted the buffer zone to be established on all borders between Syria and Turkey. However, with the developments of events, it called for a buffer zone from the city of Graves to the city of Izzaz and the town of Mare' in the west. This demand came after the control of the Kurdish protection forces over the bulk of the border and the opposition of the United States, Russia and Iran to the region. Turkey's goal in this region is to stop the influx of refugees. However, its hidden objectives are to fall Aleppo and weaken the regime (Nour AlDin, 2016).

- The establishment of a no- fly zone in northern Syria

According to Turkey, the objective of the establishment of it is to protect Syria civilians. The undeclared goal of Turkey is to prevent Syrian Kurds from controlling new areas and prevent the regime from bombing opposition strongholds.

- The overthrow of the Syrian regime

This matter might be achieved by supporting the armed groups against the regime's forces.

\section{Tools of Implementation of Turkish Foreign Policy towards Syria}

Since 2002 until the Syrian revolution, Turkey focused on soft power in its relations with Syria. The tools of soft power were diplomatic, cultural and economic. In 2010, the office of the Prime Minister established a Public Diplomacy Office to clarify Turkey's new policies with various countries and establish channels of communications with various peoples (Kalin, 2011). When Syrian revolution broke out, Turkey resorted to solid power because Syria's regime did not respond to Turkish advice.

\subsection{Diplomatic and Political Tool}

Since AKP took power, Turkey interested in the political dialogue and diplomatic initiatives in dealing with crises. The most important tools for the Turkish diplomatic performance are:

- Turkey adopted the approach of the regular diplomacy based on meeting officials in other countries (Mouawad, 2012). Since 2004, personal relations between Erdogan and Assad have been strengthened. There has been an exchange of visits. From 2003 to 2010, Davutoglu visited Syria more than 60 times (Shadid, 2011). In January 2008, Turkish President Abdullah Gul visited Damascus. This visit was the first by a Turkish President to Syria. The Turkish popular diplomacy also played a major role in deepening the bonds of cooperation between the two countries. After the occupation of Iraq in 2003, a Turkish people delegation arrived in Syria in May 2003. According to spokesman for the delegation, this visit is important to support Syria against the Israeli and American threats (Radwan, 2006). The two countries reached the stage of institutionalizing relations by establishing the strategic cooperation council in 2009. The first ministerial meeting was held in October 2009. The two countries agreed to cancel the features of entry of their citizens, and signed 30 agreements and memorandum of understanding. The second ministerial council was held in October 2010 (Mahfud, 2011).

- It urged the conflicting parties to engage in peaceful and cooperative solutions to crises. In 2008, Turkey acted as a mediator in the Syrian - Israeli negotiations. The mediation was effective where five rounds were held on sensitive issues between the Syrian and Israeli sides in 2008, which are: security arrangements, border issues, the Israeli withdrawal schedule from Golan, the file of water, and Syria's relations with Iran, Hezbollah and Hamas. Olmert agreed to abide, in writing, by borders according to the six- points document presented by Al- Assad through Turkey. However, the Israeli aggression on Gaza in 2008 led to the cessation of negotiations (Al- Quda, 2008).

In this vein, the beginning of the Syrian revolution witnessed the use of political diplomatic tools by Turkey in the form of political diplomatic pressure on Al- Assad and the proposed reform initiatives. However, Al- Assad did not respond to such initiatives. As a result, Turkey's embassy in Damascus has been closed in March 2011, but Turkey kept its consul in Aleppo. This does not mean that Turkey's political and diplomatic role in the Syrian crisis stopped. Turkey sought to continue consultations on Syrian affairs with Russia and China to create an international coalition to meet the demands of the Syrian people. This reflected in the second meeting of the friends of Syria in Istanbul in April 2012 (Mouawad, 2012). Turkey has also worked to include the Syrian file in NATO's strategies as long as the mechanism of the Security Council reminded inoperative.

In October 2012, Prime Minister Erdogan and Foreign Minister Davutoglu held talks with the Secretary- General of the Arab League, which focused on Syria. Turkey participated in the Geneva Conference in January 2014. The conference came as a result of the chemical agreement between Russia and the United States. This agreement 
disturbed Turkey because the agreement prevented the opportunity of the military strike against Al- Assad (Nour Al- Din, 2014). Turkey participated in the conference to reach a solution to the crisis, including Al- Assad's stepping down. In October 2013, Erdogan described Al- Assad as a terrorist, although he described him as a good friend until February 2011. The regime of Al- Assad, even before the revolution was authoritarian (Werz et al., 2013).

In a related context, Turkey supported the Syrian opposition. It hosted opposition conference such as, Syrian Conference on change in Antalya in June 2011, and National Rescue Conference in July 2011. The Syrian National Council was also announced from Istanbul in October 2011, as well as the National Coalition for Revolutionary forces, which opened its headquarters in Cairo and then transferred to Istanbul. Turkey also welcomed the temporary Syrian government (Sabra, 2016). Turkey sought to support the Jihadists such as AlNusra Front against the Kurdish forces in the north- east of Syria since the end of 2012, and to balance the strength of the organizations supporting the Syrian regime. Therefore, ISIS's oil was exported to Turkey with the knowledge of the Turkish government and arms smuggling.

\subsection{The Economic Tool as one of Turkey's Foreign Policy Tools towards Syria}

The AKP's view of the importance of economic dimensions is that the economy has become the guiding force of politics. Before 2002, the Arab world was not an important trading partner for Turkey. Syria was behind the Arab countries in dealing with Turkey commercially. After 2002, Turkish government's discourse showed that Turkey adopted functional approach in dealing with the issue of foreign policy. It gave priority to the development of economic relations as a prelude to the development of political relations. This approach has been used with Syria (Mouawad, 2009).

In 2004, a number of agreements have been signed between the two countries such as Prevention of Double Taxation Agreement, Protection and Promotion of Investment Agreement, and Free Trade Agreement. These agreements entered force in 2007. In 2010, Ankara agreed with Syria, Jordan and Lebanon to establish a free trade zone. Other countries were allowed to access to it. There are no visas between these countries, which may consider as establish of Middle East Union (Besheir, 2012). To support the Syrian economy, Turkey allocated in 2010 some $\$ 247$ million in loans to Syria for infrastructure projects. In 2011, Turkish companies invested about $\$ 223$ million in Syria. There was a significant increase in the number of Syrian tourists visiting Turkey, from 154.000 in 2003 to 500.000 in 2010 . As a result, the rate of foreign trade increased but the trade balance was in favor of Turkey as shown in table (1).

Table 1. The volume of Turkish exports and imports to and from Syria from 2001 to 2014

\begin{tabular}{ccc}
\hline Year & The Turkish exports to Syria & The Turkish imports from Syria \\
\hline 2001 & 281.141 & 463.476 \\
2002 & 266.772 & 314.770 \\
2003 & 410.755 & 261.193 \\
2004 & 394.783 & 247.551 \\
2005 & 551.627 & 142.585 \\
2006 & 609.417 & 187.250 \\
2007 & 797.766 & 259.282 \\
2008 & 1.115 .013 & 323.697 \\
2009 & 1.421 .637 & 221.454 \\
2010 & 1.844 .605 & 452.493 \\
2011 & 1.609 .861 & 336.646 \\
2012 & 497.960 & 67.448 \\
2013 & 1.024 .473 & 84.909 \\
2014 & 1.800 .962 & 115.499 \\
\hline
\end{tabular}

Source: Turkish Statistical Institute

However, the Syrian revolution has been broken out. The Syrian people have been suppressed be Al- Assad. Accordingly, the policy of Turkey towards Syria has been changed. In November 2011, Foreign Minister Davutoglu imposed economic sanctions on Al- Assad's regime.

\subsection{The Military Tool as one of the Tools of Turkish Policy towards Syria}

Turkey signed a security cooperation agreement with Syria in April 2009. The two sides launched the first joint ground military exercises between border forces (Mouawad, 2012). This cooperation strengthened Turkey's 
regional position and strategic depth.

After the outbreak of the Syrian revolution, the file of events in Syria was transferred to the Security Council because of the potential security threats against Turkey. In March 2012, establishing a safe and free zone was among the options that NATO should consider. In June 2012, when Syrian missiles hit the Turkish F-4 fighter, Turkey asked NATO to retaliate, based on Article 4 of the Defense Alliance, but NATO has only condemned (Drury, 2012). In October 2012, the Syrian- Turkish border witnessed significant developments leading to Turkey's military measures following the fall of Syrian missiles inside Turkey. The Turkish Parliament approved a bill allowing the army to conduct military operations outside its borders if warranted. As the threat of ISIS increased, the United States announced, in September 2014, the formation of international coalition against ISIS. Although Turkey is one of the countries which participated in the alliance, it initially refused to join its forces without an integrated strategy and international support (Bakeir, 2015). Turkey allowed only Peshmerga to go to Kobany, but did not provide military assistance. However, in July 2015, Turkey's situation changed and its force bombed the locations of ISIS in Syria in the wake of Saroj bombings. After Turkey opened Incirlik base for coalition forces, it did not participate in the campaign against ISIS except for some strikes, so that the Syrian Kurdish forces would not benefit from these strikes (Marco, 2015). The Turkish strikes of ISIS aimed to recruit the risk, so that it can intervene directly in Syria and change regional balances.

Turkey saw that the United States' failure to deal with its proposal to establish a buffer zone encouraged Moscow to intervene militarily in Syria in 2015, which changed the equations on the ground. As the events developed, battles in northern Syria were an obstacle to Turkish policy in Syria. Regime's forces and Iran- backed militias made progress in Aleppo. Also, Kurdish people's protection units penetrated within the borders of the region that Ankara wants to be safe. This means isolating Turkey from northern Syria. Kurds achieved field achievements in the north of Syria from Ain Al- Arab to Tel Abyad and finally crossing the Euphrates in the West to Manbaj. Therefore, Turkey intervened militarily in August 2016 (Grapples Operation). The regional international scene and the change in Turkey's relations with the influential forces in the Syrian crisis helped Turkey to intervene.

\subsection{The Cultural Tool}

Interpersonal communication plays an important role in Turkey's foreign policy agenda. Turkey has succeeded in transforming cultural ties into strategic assets to create a conductive environment to dialogue and cultural cooperation through a number of cultural projects and programs (Kalin, 2011). Since 2002, Turkey has been using soft power tools to make the image of Turkey attractive. The Turkish language has been taught in Damascus. Turkish Drams were shown, especially historical series, which tried to present positive visions of the Ottoman state unlike what has been circulated before. It also created relations with Arab intellectuals (AboAmoud, 2015). The Turkish media also played a key role in mobilizing public opinion on the same line as Turkish government towards the Syrian revolution. It also tried to direct active demands to the government to intervene in Syria.

\section{Assessment of Turkey's Foreign Policy towards Syria}

Since 2002 to 2010, Turkish foreign policy has succeeded in returning to the heart of regional balances and the operations of regional mobility in the region. Turkey has managed to become a reliable regional state by closer ties with Syria after 2002. The indicators of this success are that succeeding in ending Syria's embrace of the PKK, employing Syria in its regional project, entering the Arab markets and improving its negotiating position to join EU. In addition to the foregoing, Turkey became the most accepted regional and international mediator. Its mediation between Damascus and Tel Aviv was an implicit recognition of Turkey as a regional reference in the region. Syria entered Turkey to the region by changing the image of Turkey as ally of Israel, and the image of Ottoman Turkey. Turkey's mediation was more beneficial to Turkey than resolving regional problems. The Arab countries were impressed by the Turkish model and wanted to adopt it.

Despite the successes of the Turkish policy in the Arab world during the last decade, it has been subjected to a number of criticisms. For example:

- To have a good echo of zero- problems policy, Turkey should make great efforts to resolve the Kurdish issue and reach a settlement in Cyprus (Taspinar, 2011).

- Despite Turkey's important role in the Syrian- Israeli negotiations, it faced criticism because of the dominance of the security dimension in this role. This security dimension was an extension of Turkey's obligations to its relations with Israel. Some reports indicated that Erdogan transferred to Syria the need to abandon the support of Hezbollah and Hamas as prerequisites for achieving peace with Israel. However, the nature of these demands is contrary to the Turkish foreign policy towards these parties (Mouawad, 2009). 
- The analysis of the discourses of AKP's leaders showed that the concept of Neo- Ottomanism repeated more than once. According to Erdogan's speech before the party's parliamentary committee in January 2009: "Israel should know that he is the leader of an extraordinary state and the leader of Ottomans' descendants". In 2006, Gul said that "Turkey has all the historical contracts and records of the region". In a 2010 press interview with the Washington Post, Oglu noted that: "Britain had founded the Commonwealth from its former colonies and then he wondered why Turkey did not repeat its leadership in the former Ottoman territories?" (Abo- Amoud, 2015).

- Turkey's foreign policy was based on the desire to achieve an independent strategic role, coupled with its duplicity between harmonious interests with the West and the continued criticism of it.

- The contradiction regarding Turkey's attempt to export its model to the Arab countries, while it has a number of problems with regard to religious and ethnic minorities.

With the outbreak of the Syrian revolution and its developments, there was an important test of the effectiveness of the Turkish foreign policy. The Turkish action towards revolution was limited. Relations between the two countries were strained. In this context, we refer to the most important consequences of the Syrian revolution, which affected Turkey internally and externally, and represented challenges facing the Turkish role regionally. These consequences are:

- The rise of the role of Kurds: the influence of the Kurdish Democratic Union Party (BYD) and the units of the protection of the Kurdish People (YPG) escalated in the north and east of Syria. Both BYD and YPG were able to repel attacks on the city of Kobany, leading to international sympathy for the Kurdish issue. Over the course of 2014 and 2015, BYD unified the provinces under the name of Rojava. The goal is to achieve self- rule for the Kurds in Rojava (Cajaptay, 2016).

- Syrian refugee crisis: As a result of the conflict in Syria, a number of refugees were deported to Turkey. They represented a danger to the Turkish economy and national security. They constitute a large percentage of the population of the southern cities of Turkey where there are different ethnicities, leading to conflict. The Turkish government fears that the Kurdish refugees provide support for PPK.

- Influence on Turkey's regional policy: The Turkish position of the revolution resulted in the tension of Turkey's relations with Iran and Iraq. However, the relations have been strained even before the Syrian crisis because of the deals of energy between Turkey and the government of Kurdistan territory. Turkey also gave a refuge for Iraqi vice President Tariq Al- Hashemi (Yousef, 2015).

- Economic losses: Turkey suffered economic losses because of its position on revolution. Investments and trade movement have been stopped. Trade agreements have been canceled. Turkish trade, which was passing through Syria to the countries of the region, has been harmed. In addition to this, hosting the opposition and refugees was costly.

- The revival of the Russian role in the region: The chemical deal was seen by Turkey as recognition of Russia's increasing influence in the region. In September 2015, Russia intervened militarily in Syria which led to the increase of its role in the region. Russia has also worked to establish a new air base in the countryside of Latakia to be a base overlooking Syria, Turkey and the Middle East.

- The confirmation of Islamic identity of the party: Erdogan's support for the Muslim Brotherhood in Syria confirmed his ideological tendencies. This increases tension with secular opposition. Erdogan also accused the President of the Republican People's Party, Klitschidar, of supporting President Al- Assad because he was Alawi like him. Ardogan raised doubts about Al- Assad's faith. This anger the Alawites, and leading to tension. Turkey's sectarian bias in Syria has also eroded its soft power.

These repercussions affected Turkey internally, regionally and internationally. There are other reasons led to Turkey's strategic decline. These reasons are: the downfall of Morsi's government, Taksim Square's demonstrations, and the strained relations between Turkey and the United States because of Turkey's violent response to the demonstrations. The United States has expressed its concern about Turkish democracy. However, Turkey and the United States need each other. The United States needs Turkey in Syria and Iraq. Turkey needs the American weapons and intelligence. Relations between them are based on transactions that are not driven by empathy among leaders but driven by the interests of them in the Middle East (Cagaptay, 2014).

Therefore, the Turkish decision- makers began to search for how to get out of the regional impasse by reorienting foreign policy to rebalance their relations with the region in a way that does not violate their Western alliances. Turkey began to heal relations with its neighbors. It sought to approach with Iran, especially after the signing of the nuclear agreement. Turkish Foreign Minister Dovutoglu launched a new phase of relations during his visit to 
Iran in November 2013. But relations became strained in 2015 because of Erdogan's criticism of the Iranian role in Yemen. In April 2015, however, President Erdogan visited Tehran. The visit underscores Ankara's desire to maintain open relations with Iran despite disagreement on some issues (Ahmed, 2015). Turkey's policy towards Iran shows that Turkey has chosen to separate the regional political file from the file of economic relations. Turkey has also sought to overcome disagreements with Iraq and make close relations with Saudi Arabia after the fall of Sanaa by the Houthis and the Russian- Iranian alliance.

Although Turkey's foreign policy trends have been rerouted to get out of the regional impasse, Russian intervention in Syria in September 2015, then the incident of Russian aircraft that has been fallen by Turkey in November 2015. These events have posed obstacles to Turkish foreign policy. In light of these circumstances, important indicators have emerged, meaning that Turkish foreign policy has been changed, including the return of Turkish- Israeli relations. After that, the warm relations between Turkey and Russia returned, and there was relative flexibility in the Turkish position towards solving the Syrian crisis. Ankara continued to press the opposition in eastern Aleppo to leave the city. The evacuation of the armed opposition from Aleppo considered as the first fruits of the Turkish- Russian consensus. This paved the way for a triple Turkish- Russian- Iranian meeting in Moscow in December 2016, which resulted in a ceasefire agreement (Ahmed, 2016). These changes came as a result of number of challenges:

- The international situation: latest development prompted Turkey to normalize relations with Russia and reconsider its policies towards the Syrian crisis. These developments are: the position of Western countries of the failed coup in Turkey, the tension of US- Turkish relations and Turkey's fear of the American support to the Kurds.

- The security challenge: there were threats to Turkey that contributed to the change of the Turkish policy. These threats are: the threat posed by BYD and PPK, and explosions carries out by ISIS in Turkey.

- Leading variable: the change of leadership has played a key role in reorienting the Turkish foreign policy. Yildirim tried to give a more realistic dimension to Turkey's foreign policy. He took steps to improve relations with Israel, Russia, some Gulf States, Egypt and Syria.

Turkey's new positions toward the Syrian crisis have emerged. It wanted to develop good relations with Syria. Yildirim said: "Turkey hopes to have good relations with Syria and Iraq". This is a major change in Turkish policy aimed at overthrowing Al- Assad. In a related context, the failed coup in Turkey has helped Turkey to be ready for accepting a transitional period in which Al- Assad will remain temporarily. Earlier, Turkey strongly rejected any future role for Al- Assad in the transitional period. Turkey's priorities in Syria are to contain Kurdish expansionism and eliminate ISIS.

\section{Conclusion}

The growing interest of Turkey in the Arab region does not mean the reorientation of Turkish policy from the West to the East, but rather directing it to the West and the East together with employing its movements in both directions to serve the other. There has been no a radical shift in the Turkish role since AKP came to power. It remained at an intermediate level between dependence on the West and an attempt to gradually increase the margin of independence of Turkey's foreign policy without clashing with the interests of great powers in the region. The Syrian crisis proved that Turkey cannot work in Syria away from the calculations of regional and international powers.

The study shows that the Turkish foreign policy toward Syria since 2002 has gone through two phases. The first phase is from 2002 to 2011. It witnessed a turning point in relations until it reached the stage of the strategic alliance. Problems between two parties have been overcome such as water problem. However, no final solutions have been reached about these problems, which mean that they will emerge in case of tension between them. Syria was the most prominent factor in introducing the Turkish role to the region by changing the image of the allied Turkey to Israel, and the image of Ottoman Turkey. The second phase was from 2011. Relations between the two countries have deteriorated to the lowest levels as a consequence of the Turkish position of the Syrian revolution. Issues that the two parties agreed upon turned into controversial issues such as the Kurdish issue. The Turkish government has not been able to achieve the goals that it sought to by adopting certain positions towards the revolution. Turkey's action towards the revolution has a limited impact. However, Ankara, to ensure its continuation as part of the security and political arrangements formulated for Syria, has made military intervention in northern Syria. With the return of Turkish- Russian relations, Turkey moved to protect its national interests away from overthrowing Al- Assad's regime. Turkey succeeded in achieving a qualitative rapprochement with Damascus. This reflected in Syria's silence about the operation of the Euphrates Shield where it condemned it only. Also, Turkey called for security coordination with the Syrian government. 
The study has reached many conclusions, the most important of which are:

- Changing the Turkish ruling elite since 2002 and changing its perception of political reality led to the change of Turkish foreign policy towards Syria. There were personal friendly relations between the leaders of the two countries. Additionally, the geographical neighborhood. Turkey succeeded in activating the economic tool to boost Turkish- Syrian relations.

- Since 2002 Turkey has succeeded in employing soft power tools in relation to Syria. With the outbreak of the Syrian revolution and the failure of the Syrian regime to respond to Turkey's advice, Turkey resorted to the use of hard power. The Turkish role as mediator declined.

- The failure of the Turkish decision- making circle to read the complexities of the Syrian crisis is due to its failure to conceive of the resistance of the regime, the development of the Kurdish factor, Turkey's inability to unite the opposition, the threat of terrorism and its failure to read the policies of the great power.

- The Turkish government's aid to extra- state forces and parties has transformed the AKP into a party in internal conflicts in other countries.

- Contrary to the expectations of Turkish decision- makers that the Arab revolutions are a major factor in the Turkish rise in the region, the Syrian revolution, in particular, has had negative effects on Turkey. Accordingly, Turkey did not achieve its objective which it wanted. This indicates its limited role. Turkey also faced difficulties when it was trying to gather information directly from the field work in Arab countries. The number of Turkish diplomats who speak Arabic is far less than the number of western ones. Finally, the Syrian crisis showed that Turkey cannot work in Syria away from the calculations of regional and international powers.

- The AKP has reconsidered ideology as a key determinant of foreign policy. This was demonstrated by supporting the establishment of Islamic systems.

- Turkey sought to employ the issue of refugees to achieve political goals. It called for a no- fly zone in northern Syria to protect refuges, while its real aim is to secure supplies for the Syrian opposition.

- Dispute between Syria and Turkey will affect its regional strategy. Also, Turkey's support for Jihadists has also put Turkey as a state sponsoring terrorism.

- The aim of Turkey of strikes of ISIS since July 2015 is to employ the danger of ISIS to intervene directly in Syria.

- Despite the influence of ideology in Turkey's foreign policy, it declined in the face of the state's material interests. In the case of clash between ideology and interests, the decision maker choses material interests. This was evident in the change of Turkish foreign policy towards the regional and international parties after the failed coup in Turkey.

- $\quad$ Turkey succeeded in finding a foothold in Syria through Euphrates Shield Operation in August 2016. It became also a sponsor partner of the path of Astana successfully. Despite the improvement of TurkishRussian relations, Turkey cannot be part of Russian- Iranian axis.

- Despite difficulties facing Turkey's foreign policy, it has mechanisms affecting the region's calculations. A realistic estimation of the balance of power in the Middle East cannot be achieved without taking Turkey into account.

\section{Recommendations}

Turkey as an important state in the region - whatever we agree or disagree with Erdogan - and it will play a regional role according to the determinants of its international ally, not according to Erdogan's ambitions. Based on the aforesaid conclusions, the study set a number of recommendations. They are as follows:

- Turkey should disengage crises in its relations with regional and international parties, and should keep itself away from the approach of its impulsive policy towards the regional issues. Also, it must avoid the political and media escalation because it would lose the pragmatism of its political discourse.

- Turkey should not interfere in the internal affairs of the Arab countries to maintain its positive image towards the Arab people, while it maintains its national security.

- The collapse of Syria - an Arab neighbor of Turkey - is not in the interest of Turkey because it will change the map of the Middle East. Therefore, there must be an Arab - Turkish - Iranian understanding to preserve the sovereignty and stability of all countries in the region. 
- In case of the return of Turkish- Syrian relations, historical differences must be overcome by finding a solution that satisfies the two parties. Regarding the issue of water, Turkey must abide by the principles of international law regarding the regulation of the exploitation of international rivers water. Also, Syria and Iraq must adopt a common policy to preserve their legitimate rights in the Tigris and Euphrates rivers. Regarding the Kurdish issue, common solutions must be found for this issue based on recognition of cultural and national rights for the two countries, which is done within the scale of national unity of each state.

\section{References}

Abdul Aziz, O. (2008). In the Syrian- Israeli Negotiations: Turkish Water as a price for the Return of the Ottomans as a Third Regional Alternative in the Region. Al-Ahram Newspaper, No. 44373.

Abu Amoud, M. S. (2015). Turkey and Dream of Reproduction of the Ottoman Caliphate State. Al-Siyassa AlDawliya Journal, (201), 100-104.

Ahmed, S. M. (2016). Motivations and Implications: The Syrian Crisis and the Transformation of the Turkish Role. Turkish Affairs Journal, (6), 87-89.

Al- Awda, M. (2015). The Story of the Syrian- Israeli Negotiations in Turkey in 2008. Arab Journal of Political Science, (48), 76-78.

AL-Anani, K. (2010). With the United States of America Strategic interests. In Turkey between External Challenges and External Bets. Cairo: Arab Science House.

Anonymous, (2016). Pragmatic Transformations: The Engine of Rotating Turkey's Foreign Policy. Arab Strategic Report. Al- Ahram Center for Political and Strategic Studies.

Aras, D. (2012). Turkish- Syrian Relations go Down Hill. Middle East Quarterly, 19(2), 45-50.

Bakeir, A. H. (2015). The Determinants of the Turkish Policy Towards the International Alliance. Al-Siyassa AlDawliya Journal, (99), 112-114.

Bakir, A. H. (2013). The Geopolitical Dimensions of Iranian and Turkish Policy Towards Syria. Doha: Arab Center for research and policy studies.

Bar, A. (2006). Turkish Foreign Policy survey: Directions and Dilemmas in 2007. Perceptions Journal, Autumnwinter, 37-57. Retrieved from http://sam.gov.tr/wp-content/uploads/2012/02/AllonBar.pdf

Barkey, H. J. (2016). Erdogan's Foreign Policy Is in Ruins. Foreign Policy. Retrieved from http://www.foreignpolicy.com/2016/02/04/erdogans-foreign-policy-is-in-ruins

Bashir, H. (2012). Common Losses: The Regional and Economic implications of the Syrian Crisis. AL-Siyassa Al- Dawliya Journal, 190(86).

Cagaptay, S. (2014). Discussing Turkey's Latest Foreign Policy Challenges. Retrieved from Ahmed, S. M. (2015). Erdogan's Visit to Iran: Comparativness or regional consensus. Cairo: Al- Ahram Center for Political and Strategic Studies. Retrieved from_http://www.washingtoninstitute.org/policy-analysisdiscussing-turkeys-latest-foreign-policy-challenges

Cagaptay, S. (2016). Turkish-Russian Ties after the Erdogan-Putin Breakthrough. The Washington Institution for Near East Policy. Retrieved from http://www.washingtoninstitute.org/policy-analysis/view/turkishrussian-ties-after-the-erdogan-putin-breakthrough

Demir, I. (2017). Turkey's Foreign Policy towards the Middle East: Under the Shadow of the Arab Spring. UK: Cambridge Scholar Publishing.

Drury, I. (2012). Turkey Pleads for NATO Intervention over Fighter Shot Down by Syria. Daily Mail. June 24.

El-Labad, M. (2013). The Iranian- Turkish Conflict on Syria and the Arab Vacuum. Bidayat Journal, 29-32.

Fatappie, M. (2012, March 23). Turkey Eyes Syrian Crisis through Lens of Kurdish Stability. The National Newspaper. Retrieved from http://www.thenational.ae/turkey.eyes.syrian-crisis-through-lens-of-kurdishstability-1.365196

Hinnebush, R. (2015). Back to Enmity: Turkey- Syrian Relations since the Syrian Uprising. Orient Journal, 56(1), 18-22. http://www.acrseg.org/36638

Ibrahim, A. (2015). The Development of Turkish-Syrian Relations in the Period from 2000 to 2012 (Unpublished doctoral dissertation). Cairo: Faculty of Economics and Political Science. 
Kalim, I. (2011). Turkish Foreign Policy: Framework, Values and Mechanisms. International Journal, 12, 19-21.

Kalin, I. (2011). Soft Power and Public Diplomacy in Turkey. Perceptions Journal, 3, 7-8.

Kardas, S. (2011). Turkish- American Relations in the 2000: Revisiting the Basic Parameters of Partnership. Perceptions Journal, 16(3), 7-32.

Mahfoud, A. S. (2009). Syria and Turkey: Current Reality and Future Prospects. Beirut: Center for Arab Unity Studies.

Marco, J. (2015). The International and Domestic Implications of Turkish Policies in Syria. Arab Policy Journal, 92-95.

Mohamed, A. A. (2013). The Doctrinal Political Method of Rajab Tayyip Erdogan. Ruaa Aistiratijia Journal, (3), 15-16.

Mohfoud, A. (2011). Syrian- Turkish Relations: Transformations and Bets. Doha: Arab Center for Research and Policy Studies.

Mouawad, A. G. (2009). The Turkish Vision for Regional Security in the Middle East. Middle East Papers Journal, (43), 52-55.

Mouawad, A. G. (2009). Turkey's Regional Role in the Middle East Region (2002- 2007). (Unpublished master's thesis). Cairo: Faculty of Economics and Political Science.

Mouawad, A. G. (2012). Turkish Foreign Policy in the Arab Region Under the Governments of Justice and Development. Cairo: Institute of Arab Research and Studies.

Noureldein, M. (2014, January 24). Turkey in Geneva 2: Looking for an Opportunity that will not come. AlSafir Newespaper.

Noureldein, M. (2016). The Course of Turkish Policy in the Midst of Events in the Region. Sho'un Arabia Journal, (165), 52-53.

Radwan, W. (2006). Arab- Turkish Relations. Beirut: Company of Publishing for Press.

Shadid, A. (2011). Turkey calls for Syrian Reforms on order of Shock Therapy. New York Times, May 26, P. 8.

Sobara, G. (2016). Turkey and the Syrian Opposition: Open Door Policy. Journal of Opinions of the Gulf, (105), 78-79.

Taspinar, O. (2011). Turkey's New Regional Diplomacy: Ambitions and Constraints. Retrieved from https://www.brookings.edu/events/turkeys-new-regional-diplomacy-ambitions-and-constraints/

Taya, M. S. (2012). Hydrolytic Relations in the Regional Regime of the Tigris and Euphrates Rivers. In Turkey: Survey Study. Cairo: Arab Organization for Education, Culture and Science.

Trenin, D. (2014). Russia's Interests in Syria. Retrieved from http://carnegie.ru/2014/06/09/russia-s-interestsin-syria-pub-55831

Werz, M. et al. (2013). Turkey's Foreign Policy Challenges. Rethink Conference, 4.

Yildirim, B. (2016). Turkey Seeks to Develop Good Relations with Syria. Retrieved from http://www.bbc.com/arabic/middleeast/2016/07/160713_turkey_syria_relationship_development

Yousef, E. (2015). Turkey: Ambitious Strategy and Restrictive Policy: A Geopolitical Approach. Abu Dhabi: Emirates Center for Strategic Studies and Research.

Yousef, M. K. (2013). The Development of Turkish- Syrian Political Relations in the Light of Regional International Changes (2007- 2012) (Unpublished master's thesis). Cairo, Faculty of Arts and Human Sciences.

\section{Copyrights}

Copyright for this article is retained by the author(s), with first publication rights granted to the journal.

This is an open-access article distributed under the terms and conditions of the Creative Commons Attribution license (http://creativecommons.org/licenses/by/4.0/). 